\title{
STUDI ANALISIS LOGAM RUNUT NIKEL DAN KOBALT DALAM BATUAN SAPROLTT DENGAN METODA EKSTRAKSI DAN PENGENDAPAN
}

\author{
Gunawan, Mudji Triatmo MA \\ Jurusan Kimia FMIPA Universitas Diponegoro
}

\begin{abstract}
ABSTRAK
Logam nikel dan kobalt dalam batuan saprolit berada dalam jumlah runut. Studi analisis logam rumut nikel dan kobalt dalam batuan tersebut telah dilakukan dengan metoda ekstraksi dan pengendapan. Juga dipelajari penganih logam besi dalam jumlah mayor terhadap analisis kedua logam tersebut. Analisis dilakukan dengan SSA. Ekstraksi Ni dan Co menggunakan DMG dengan pelarut PE memberikan hasil lebih sedikit dibandingkan dengan pelarut kloroform, sedangkan metoda pengendapan dengan pengujian SSA memberikan hasil yang jauh lebih baik daripada dengan ekstraksi pelarut kloroform. Analisis Ni dengan cara gravimetri sebanyak 10,426\%. Hasil tersebut lebih besar kanena efek kopresipitasi. Data $K_{D}$ mentunjukkan bahwa analisis nunut Ni akan lebih baik kalau sampel saprolit tersebut diekstraks dalam pelarut kloroform, karena besi tidak banyak terekstraks dibandingkan dengan pelarut PE. Untuk analisis nunut Co akan lebih baik kalau diekstraks dalam pelarut PE dan yang dianalisis sisa ekstraksnya, karena kobalt sebagian besar berada pada sisa ekstraks dan jumlah besi sangat sedikit, sehingga gangguan besi dapat dihilangkan.
\end{abstract}

Kata kunci: ekstraksi pelant, DMG, safrolit.

\begin{abstract}
Trace amounts of Nickel and Cobalt are contained in saffrolite minerals. The study of trace amount analyses two of which in the rocks had been done using the methods of solvent extraction and precipitation as well as the effect of iron as mayor component against the anaysis. The metals were analyzed using atomic absorption spectrophotometer. Extractions of nickel and cobalt using DMG gave less result with petroleum ether than chlonform solvent, mean-while precipitation method determined with AAS gave a better result than the extraction using chloroform solvent. Nickel analysis using method of gravimetry gave result of $10.426 \%$. The result was much higher due to coprecipita-tion effect. From the $K_{D}$ values showed that the analysis of nickel would be better if the saffrolite sampel was extracted in the chloroform solvent, since iron was less extracted in cloroform than petroleum ether solvent. On the contrary, analysis of cobalt would be better if the sampel was extracted in the petroleum ether than chloroform solvent. Since the concentration of iron was low but higher for cobalt in the filtrate, so the filtrate was analyzed in order to reduce iron interference.
\end{abstract}

Keyword: Solvent extraction, dimethilglioxime (DMG), saffrolite.

\section{PENDAHULUAN}

\section{Latar belakang masalah}

Batuan saprolit (Saffrolite) banyak mengandung logam besi sebagai unsur mayor dan terasosiasi logam nikel, kobalt, arsen dan perak sebagai logam runut ${ }^{1)}$. Analisis logam runut dengan adanya besi sebagai unsur mayor memerlukan teknik pemisahan agar besi tidak mengganggu. Untuk analisis nikel dan kobalt dalam jumlah rumut dilakukan ekstraksi dan pengendapan sebelum analisis dilakukan. Dengan melihat hasil analisis dapat dipelajari pengaruh ekstraksi dan pengendapan terhadap hasil analisis runut tersebut.

\section{Metoda ekstraksi}

Distribusi suatu solut antara dua fasa yang saling tidak melarut adalah suatu proses kesetimbangan yang meng-ikuti hukum aksi massa. Jika dimisalkan solut spesies A terdistribusi antara fasa air dan fasa organik, hasil kesetimbangannya dapat ditulis:

$$
\mathrm{A}_{\text {air }} \longrightarrow \mathrm{A}_{\text {org }}
$$

Idealnya perbandingan aktivitas $\mathrm{A}$ dalam dua fasa konstan dan tidak tergantung pada banyaknya total A. Sehingga pada temperatur tertentu diberikan:

$$
\mathrm{K}_{\mathrm{D}}=\left[\mathrm{A}_{\text {org }}\right] /\left[\mathrm{A}_{\mathrm{air}}\right]
$$

$\mathrm{K}_{\mathrm{D}}$ adalah koefisien distribusi

Koefisien distribusi memungkinkan untuk menetapkan kondisi eksperimen yang diperlukan untuk mengambil suatu solut dari satu pelarut ke pelarut yang lain. Untuk n kali ekstraksi akan diperoleh persamaan ${ }^{2)}$

$$
\left[A_{\text {air }}\right]=\left(\frac{V_{\text {air }}}{V_{\text {org }} K_{D}+V_{\text {air }}}\right)^{n}\left[A_{\text {ari }}\right]_{\text {org }}
$$

$\mathrm{V}_{\text {air }}$ adalah volume fasa air dan $\mathrm{V}_{\text {org }}$ adalah volume fasa organik yang digunakan.

Penerapan ekstraksi sering lebih menarik daripada pengendapan untuk pemisahan spesies anorganik dan 
prosedur ekstraksi sesuai untuk pemisahan spesies anorganik dalam jumlah runut.

Ekstraksi senyawa anorganik banyak menggunakan pengompleks organik membentuk senyawa khelat. Khelat tersebut dapat larut dalam pelarut organik tertentu seperti kloroform, karbontetraklorida, benzena dan eter. Sehingga memungkinkan pemisahan secara kuantitatif ion logam pada fasa organik. Dalam penelitian digunakan dimetilglioksim sebagai pengompleks dengan pelarut kloroform dan petroleum eter.

\section{Metoda pengendapan}

Metoda pengendapan merupakan salah satu metoda gravimetri yang didasarkan pengukuran massa. Prinsipnya analit (solut) diubah menjadi endapan yang sukar larut, endapan itu kemudian disaring, dicuci bebas dari pengotor dan diubah menjadi hasil yang diketahui komposisinya oleh pemanasan yang sesuai. Hasilnya selanjutnya ditimbang. Idealnya zat pengendap dalam metoda pengendapan harus bereaksi secara spesifik atau jika tidak secara selektif dengan analit. Reagen pengendap spesifik jarang diperoleh, hanya bereaksi dengan spesies kimia tunggal. Reagen pengendap selektif sering dijumpai di lab, hanya bereaksi dengan sejumlah spesies yang terbatas. Salah satu contoh reagen pengendap selektif adalah dimetilglioksim.

\section{BAHAN-ALAT}

Bahan: dimetil glioksim, asam sulfat $96 \%$, asam flourida $48 \%$, asam nitrat $63 \%$, akuades, nikel klorida, ferri klorida, ammonium hidroksida, ammonium sitrat, asam boraks, petroleum eter, kloroform.

Alat: piala teflon, corong pisah, neraca analitik listrik, SSA PE 3110.

\section{METODA}

\section{Preparasi sampel}

Sampel saprolit yang sudah dihaluskan sebanyak 1,000 gram dimasukkan ke dalam piala teflon, dibasahi dengan sedikit akuades, ditambah $10 \mathrm{~mL}$ HF sedikit demi sedikit, kemudian ditambah asam sulfat pekat $3 \mathrm{~mL}$. Piala teflon ditutup dan dipanaskan dalam penangas air pada suhu $70^{\circ} \mathrm{C}$ selama 3 jam. Selanjutnya tutup teflon dibuka, diuapkan sampai volume $3 \mathrm{~mL}$ kemudian ditambahkan $1 \mathrm{~mL}$ asam nitrat pekat. Pemanasan diteruskan sampai timbul endapan putih. Setelah didinginkan ditambahkan $10 \mathrm{~mL}$ asam boraks $10 \%$. Selanjutnya isi piala teflon dipindahkan ke dalam gelas piala $250 \mathrm{~mL}$ dan ditambah $100 \mathrm{~mL}$ akuades. Larutan tersebut lalu dididihkan sampai nampak jernih, setelah dingin isi gelas piala dipindahkan secara kuantitatif ke dalam labu takar $250 \mathrm{~mL}$ dan ditambahkan akuades sampai batas.

\section{Preparasi larutan dimetil glioksim}

Sebanyak 1,000 gram dimetilglioksim dilarutkan dalam $500 \mathrm{~mL}$ ammonium hidroksida dan selanjutnya diencerkan sampai 1 liter.

\section{Ekstraksi dengan dimetilglioksim (DMG) dalam pelarut petroleum eter}

Kedalam corong pisah dimasukkan sampel sebanyak $100 \mathrm{~mL}$, selanjutnya ditambahkan $20 \mathrm{~mL}$ dimetilglioksim, 5 gram asam sitrat dan $20 \mathrm{~mL}$ petroleum eter. Corong pisah tersebut lalu digojok kuat-kuat, dikeluarkan gasnya, didiamkan beberapa saat, fasa organiknya diambil dan dilucuti dengan $10 \mathrm{~mL} \mathrm{HCl} 4 \mathrm{M}$, kemudian volumenya dijadikan $100 \mathrm{~mL}$. Fasa air dan fasa organik yang sudah dilucuti ditetapkan kandungan nikel, kobalt dan besi dengan SSA.

\section{Ekstraksi dengan dimetilglioksim (DMG) dalam pelarut kloroform}

Prosedurnya sama dengan ekstraksi dengan DMG di atas hanya saja pelarutnya menggunakan kloroform.

\section{Pengendapan dengan DMG}

Ke dalam gelas piala yang terdapat $12,5 \mathrm{~mL}$ sampel ditambahkan $10 \mathrm{~mL} \mathrm{DMG}$, setelah terjadi pengendapan disaring, dioven dan ditimbang. Kemudian endapan tersebut dilarutkan kembali dalam $\mathrm{HCl} 4 \mathrm{~N}$ sampai larut semua. Selanjutnya ditetapkan kandungan nikel, kobalt dan besi dengan SSA.

\section{HASIL DAN PEMBAHASAN}

Konsentrasi logam sebelum perlakuan dan setelah perlakuan dan harga $K_{D}$ ekstraksi Ni-DMG dengan pelarut $\mathrm{PE}$ dan kloroform masing-masing disajikan pada tabel 1 dan 2.

Hasil pengendapan (dari penimbangan $)=0,5132 \mathrm{~g}$. Dengan mengalikan faktor gravimetrinya untuk NiDMG diperoleh kadar $\mathrm{Ni}=10,426 \%$. 
Tabel 1. Konsentrasi logam sebelum perlakuan dan setelah perlakuan

\begin{tabular}{|l|l|c|c|c|}
\hline \multirow{2}{*}{ No. } & \multicolumn{3}{|c|}{ Sampel } & \multicolumn{3}{|c|}{ Konsentrasi (mg/L) } \\
\cline { 3 - 5 } & & $\mathbf{N i}$ & Fe & Co \\
\hline 1. & Sampel awal & 93,290 & 727,4 & 1,21 \\
2. & Ekstraks PE & 47,610 & 558,8 & 0,11 \\
3. & Sisa Ekstraks PE & 28,119 & 3,715 & 1,01 \\
4. & Ekstraks Kloroform & 57,600 & 528,0 & 0,96 \\
5. & Sisa Ekstraks kloroform & 28,400 & 248,0 & 1,72 \\
6. & Hasil pengendapan(AAS) & 63,139 & 484,0 & 0,86 \\
\hline No. & Sampel & \multicolumn{3}{|c|}{ Konsentrasi (\%) } \\
\cline { 3 - 5 } & & $\mathbf{N i}$ & Fe & Co \\
\hline 10. & Sampel awal & 2,330 & 18,185 & 0,030 \\
2. & Ekstraks PE & 1,190 & 13,970 & 0,003 \\
3. & Sisa Ekstraks PE & 0,703 & 0,0930 & 0,025 \\
4. & Ekstraks Kloroform & 1,440 & 13,200 & 0,021 \\
5. & Sisa Ekstraks kloroform & 0,710 & 6,200 & 0,018 \\
6. & Hasil pengendapan(AAS) & 1,578 & 12,100 & 0,240 \\
\hline
\end{tabular}

Tabel 2. Harga $K_{D}$ ekstraksi Ni-DMG dengan pelarut PE dan kloroform

\begin{tabular}{|l|c|c|c|}
\hline \multirow{2}{*}{ Jenis pelarut } & \multicolumn{3}{|c|}{$\mathbf{K}_{\mathbf{D}}$ (Koefisien distribusi) } \\
\cline { 2 - 4 } & $\mathbf{N i}$ & $\mathbf{F e}$ & $\mathbf{C o}$ \\
\hline $\mathrm{PE}$ & 1,69 & 150,22 & 0,12 \\
Kloroform & 2,03 & 2,13 & 1,17 \\
\hline
\end{tabular}

Komposisi Ni dengan ekstraksi menggunakan pelarut PE memberikan hasil yang lebih banyak pada sisa ekstraks, artinya bahwa sampel tersebut tidak terekstraks dengan baik menggunakan PE. Hal ini terlihat dengan harga $K_{D}$ sebesar 1,59 , sedangkan pada ekstraksi dengan pelanut kloroform memberikan hasil yang lebih baik dengan $K_{D}$ sebesar 2,03. Tetapi metoda pengendapan yang kemudian dilarutkan lagi dan diuji kada $\mathrm{Ni}$ dengan SSA memberikan hasil yang lebih baik daripada jenis perlakuan dengan ekstraksi pelarut kloroform. Hal ini berarti metoda pengendapan sebagai bentuk analisis $\mathrm{Ni}$ memberikan hasil yang baik untuk logam runut asal dilarutkan kembali dan diuji larutannya dengan metoda lain yang lebih sensititf. Perolehan $\mathrm{Ni}$ dengan cara pengendapan, dengan metoda gravimetri diperoleh sebanyak $10,426 \%$. Terlihat disini bahwa metoda gravimetri dengan cara pengendapan akan memberikan kesalahan kalau endapan Ni-DMG yang didapatkan sangat kecil, karena kesalahan penimbangan akan sangat besar.

Nampak bahwa dalam endapan tersebut masih banyak mengandung besi, sehingga kalau keberadaan besi dapat mengganggu uji $\mathrm{Ni}$ dalam jumlah runut, maka cara gravimetri pengendapan tidak diperkenankan. Dalam sampel mula-mula terlihat besi merupakan unsur mayor dalam batuan saprolit. Ekstraksi besi dengan DMG menggunakan pelarut $\mathrm{PE}$ memberikan hasil yang lebih baik (sisa hasil ekstraksnya sedikit) $\mathrm{K}_{\mathrm{D}}$ dengan sebesar 150,22. Sedangkan untuk ekstraksi menggunakan pelarut kloroform ekstraksi besi tidak banyak dengan $K_{D}$ sebesar 2,13. Pada uji besi dengan cara pengendapan memberikan hasil yang tinggi, meskipun tidak setinggi kadar besi pada sampel mulamula. Sehingga dengan demikian akan memunculkan efek kopresipitasi. Hal ini pula yang menyebabkan kadar Ni pada cara gravimetri memberikan hasil yang lebih besar dibandingkan analisis $\mathrm{Ni}$ hasil pengendapan dengan SSA.

Kadar kobalt dalam saprolit relatif paling kecil hasilnya. Pada ekstraksi Co-DMG menggunakan pelarut PE memberikan hasil sebesar $0,002 \%$ dengan $\mathrm{K}_{\mathrm{D}}=$ 0,12 . Hal ini berarti kobalt tidak dapat terekstraks dengan baik pada fasa PE, berbeda dengan fasa kloroform yang terekstraks relatif lebih banyak sekitar $0,021 \%$ dengan $\mathbf{K}_{\mathbf{D}}$ sebesar 1,17 . Sedangkan dengan cara pengendapan perolehan kobalt relatif hampir sama dengan sampel mula-mula.

Dari data $\mathrm{K}_{\mathrm{D}}$ untuk masing-masing pelarut terlihat bahwa untuk analisis runut $\mathrm{Ni}$ dan Co dengan adanya unsur mayor besi, maka analisis $\mathrm{Ni}$ akan baik kalau dalam pelarut klóroform dengan $K_{D}$ sebesar 2,03 dan besi tidak terlalu banyak terekstraks dibandingkan dengan pelarut PE. Dan analisis runut Co akan baik kalau sampel saprolit tersebut diekstraks dengan PE dan yang diuji untuk analisis kobalt adalah sisa ekstraksnya, karena kobalt sebagian besar berada pada sisa ekstraks PE sedangkan junlah besi sangat sedikit. Sehingga dengan teknik ekstraksi tersebut diharapkan gangguan besi dapat dihilangkan.

Tabel 3. Perolehan kembali

\begin{tabular}{|l|c|c|c|}
\hline \multicolumn{1}{|c|}{ Jenis sampel } & Ni & Fe & Co \\
\hline Sampel awal & 2,330 & 18,185 & 0,030 \\
Ekstraks dan sisa ekstraks PE & 1,893 & 14,063 & 0,028 \\
Ekstraks dan sisa ekstraks kloroform & 2,150 & 19,400 & 0,039 \\
\hline
\end{tabular}

\section{UCAPAN TERIMA KASIH}

Atas penggunaan fasilitas laboratorium Kimia Analitik Fakultas MIPA Universitas Gadjah Mada Yogyakarta hingga terselesaikannya penelitian ini.

\section{PUSTAKA}

1. Picot, P. and Johan, Z., 1982, Atlas of ore minerals, Guilloux, J. (translation), Watkinson, D.H. (ed.) Elsevier, Amsterdam. 
2. Anonim, 1994, Analytical Methods for Atomic Absorption Spectroscopy, The Perkin Elmer Corp., USA.

3. Sandell, E., B. dan H Onishi, 1978, Colorimetric Determination of Traces of Metals, $4^{\text {th }}$ edition, Interscience, New York.

4. Skoog, D.A., 1985, Principles of Instrumental Analysis, $3^{\text {rd }}$ edition, Saunders College Publishing, Philadelphia.

5. Pecsock, R.L., et al., Modern Methods of Chemical analysis, 1968, $2^{\text {nd }}$ edition, John Wiley \& Sons, New York. 